\title{
Effects of Metal Ions on the Catalytic and Thermodynamic Properties of the Aminopeptidase Isolated from Pronase
}

\author{
Chien-Hou Wu and Wann-Yin Lin \\ Department of Chemistry, National Taiwan University, Taipei, Taiwan
}

\begin{abstract}
The effect of metal ions on the catalytic and thermodynamic properties of the aminopeptidase isolated from pronase has been investigated. A decrease in $K_{M}$ and enhanced activity were observed for most of the metal ions examined. $\mathrm{Ca}(\mathrm{II})$ exhibits the most prominent effect on enzyme activity. The observed stability constants for the enzyme-bound metal ions are in the range of $10^{2}-10^{6} \mathrm{M}^{-1}$, which is much smaller than that of a metalloenzyme, indicating that the metal ion is not an integral part of the enzyme. The complexation of L-leucine-p-nitroanilide and the transition metal ions causes a reduction in free substrate concentration and hence a concomitant decrease in enzyme activity. Therefore, care must be taken to account for this decrease in substrate concentration in order to obtain reliable kinetic parameters. Binding of $E$ and $S$ to form ES was accompanied by a decrease in Gibbs free energy, whereas a dramatic increase in the free energy was observed for the conversion of ES to $\mathrm{ES}^{\ddagger}$. Both the enthalpy and the entropy were found to be crucial in destabilizing $\mathrm{ES}^{\ddagger}$. In the presence of $\mathrm{Ca}(\mathrm{II}), \mathrm{ES}$ is stabilized by $\sim 1 \mathrm{kcal} / \mathrm{mol}$ and $\mathrm{ES}^{\ddagger}$ by $\sim 1.4 \mathrm{kcal} / \mathrm{mol}$. The stabilization of $\mathrm{ES}$ by the presence of $\mathrm{Ca}(\mathrm{II})$ is reflected by a smaller $\mathrm{K}_{\mathrm{M}}$ value compared to that of the metal-free enzyme. The activation free energies for the process $\mathrm{E}+\mathrm{S} \rightarrow \mathrm{ES}^{\ddagger}$ were 10.8 and $9.4 \mathrm{kcal} / \mathrm{mol}$ for the metal-free and the $\mathrm{Ca}$ (II)-activated enzymes, respectively. The difference of $\sim 1.4 \mathrm{kcal} / \mathrm{mol}$ in the activation free energy may account for enhanced activity by the presence of $\mathrm{Ca}$ (II).
\end{abstract}

\section{ABBREVIATIONS}

Hepes, (N-[2-hydroxyethyl] piperazine- $\mathrm{N}^{\prime}$-[2-ethanesulfonic acid); LPNA, L-leucine-p-nitroanilide; AP-I, aminopeptidase-I; ES, ground-state enzyme-substrate complex; ES ${ }^{\ddagger}$, transition-state enzyme-substrate complex.

Address reprint requests to: Professor Wann-Yin Lin, Department of Chemistry, National Taiwan University, Roosevelt Road, Section 4, Taipei, Taiwan 10764. 


\section{INTRODUCTION}

The involvement of metal ions in metalloprotease catalysis has long been recognized [1]. The metal ion is considered to be an integral part of the protein structure and is likely to enhance the nucleophilicity of water, to polarize the peptide bond to be cleaved, or to stabilize the transition state of the enzymesubstrate complex [2,3]. Recently, we purified from pronase two monomeric aminopeptidases with molecular masses of $32 \mathrm{kDa}$ [4]. These two enzymes are very similar and do not necessarily require metal ions for activity. However, the presence of a calcium ion was found to dramatically enhance the activity and thermal stability of the enzyme. Chemical modification of the aminopeptidase also revealed that the calcium ion plays an important role in substrate binding and turnover, in particular for the enzyme with one histidine being modified [4]. In order to obtain further insights into the roles of metal ions in enzyme catalysis, we have investigated the effect of different metal ions on the catalytic properties of these enzymes and have determined the thermodynamic parameters for the enzyme-catalyzed reactions. The enzyme activity was modified to various extents by the presence of different metal ions with $\mathrm{Ca}$ (II) exhibiting the most prominent effect. The presence of a calcium ion was found to stabilize both the ground state and transition state of the enzyme-substrate complexes. Furthermore, the peptide substrates are capable of finding some transition metal ions. The formation constants of the substrate-bound metal ions have also been determined. This complexation process has to be taken into account in dealing with the kinetic results in order to obtain reliable kinetic parameters.

\section{EXPERIMENTAL}

\section{Materials}

Pronase $\mathrm{E}$, all metal salts, $\mathrm{NaOH}$, and $\mathrm{HCl}$ were purchased from $\mathrm{E}$. Merck (Darmstadt, Germany). Hepes and LPNA were obtained from Sigma Chemical Co. (St. Louis, MO, U.S.). Procedures for metal-free water (with a resistivity of $18 \mathrm{M} \Omega / \mathrm{cm}$ ), buffers, plastic wares, and dialysis tubings were conducted as recommended [5-7]. The purification of aminopeptidases from pronase was performed as described previously [4]. The absorption measurements were performed on a Hitachi U-3210 spectrophotometer (Hitachi, Japan).

\section{Effect of Metal Ions on Enzyme Activity}

The enzyme activity against LPNA was determined by monitoring the absorbance change at $405 \mathrm{~nm}$ using a molar absorptivity of $9900 \mathrm{M}^{-1} \cdot \mathrm{cm}^{-1}$ [8]. The enzyme was dialyzed extensively against $10 \mathrm{mM}$ Hepes (pH 8.0) at $4^{\circ} \mathrm{C}$ to remove the calcium ion (which is not very tightly bound, as shown later) introduced during purification. Dialysis of the enzymes with EDTA is not necessary for the preparation of the metal-free enzymes because the activities for the EDTA-treated and the buffer-dialyzed enzymes are found to be the same. The enzyme was also assayed for its metal contents by inductively coupled plasma-mass spectrometer and the results indicated the absence of $\mathrm{Zn}$ (II) (the most common metal ion in aminopeptidase) and $\mathrm{Ca}$ (II). The absence of other 
metal ions may result from the treatment of the proteins with EDTA during the purification process [4]. The metal-free enzyme was incubated at $25^{\circ} \mathrm{C}$ in the presence of $1 \mathrm{mM}$ of the appropriate metal ion to be studied in $10 \mathrm{mM}$ Hepes, $\mathrm{pH} 8.0$, for $30 \mathrm{~min}$ and the kinetic parameters $\left(\mathrm{k}_{\mathrm{cat}}\right.$ and $\left.\mathrm{K}_{\mathrm{M}}\right)$ were determined by the conventional initial-rate method.

The reaction mechanism for the metal-dependent AP-I is described in Scheme 1 [9] with the corresponding variations in $k_{c a t}, K_{M}$, and $k_{c a t} / K_{M}$ as functions of metal ion concentrations given by:

$$
\begin{gathered}
\mathrm{k}_{\mathrm{cat}}=\mathrm{k}_{\mathrm{p}}\left(\alpha \mathrm{K}_{\mathrm{D}}+\beta[\mathrm{M}]\right) /\left(\alpha \mathrm{K}_{\mathrm{D}}+[\mathrm{M}]\right), \\
\mathrm{K}_{\mathrm{M}}=\mathrm{K}_{\mathrm{S}}\left(\mathrm{K}_{\mathrm{D}}+[\mathrm{M}]\right) /\left(\mathrm{K}_{\mathrm{D}}+[\mathrm{M}] / \alpha\right), \\
\mathrm{k}_{\mathrm{cat}} / \mathrm{K}_{\mathrm{M}}=\left(\mathrm{k}_{\mathrm{p}} / \mathrm{K}_{\mathrm{S}}\right)\left(\mathrm{K}_{\mathrm{D}}+\beta[\mathrm{M}] / \alpha\right) /\left(\mathrm{K}_{\mathrm{D}}+[\mathrm{M}]\right),
\end{gathered}
$$

where $[\mathrm{M}]$ is the metal ion concentration. Other parameters are defined in Scheme 1. Consequently, measurements of $\mathrm{k}_{\mathrm{cat}}, \mathrm{K}_{\mathrm{M}}$, and $\mathrm{k}_{\mathrm{cat}} / \mathrm{K}_{\mathrm{M}}$ at various metal ion concentrations allow the determination of $\mathrm{K}_{\mathrm{D}}, \alpha$, and $\beta$ from the curve fittings of Eqs. (1)-(3).

\section{Measurements of the Binding Constants of LPNA and Metal Ions}

The absorption spectrum of LPNA was dramatically changed upon addition of some transition metal ions. For $\mathrm{Ni(II),} \mathrm{Co(II),} \mathrm{and} \mathrm{Zn}(\mathrm{II})$, a $1: 1$ complex is formed and the absorbance at a given wavelength, $\mathrm{A}$, is given by:

$$
A=\left(A_{0}+A_{1} K_{f}[M]\right) /\left(1+K_{f}[M]\right)
$$

where $A_{0}$ and $A_{1}$ are the absorbances of the free LPNA and the metal-LPNA complex, respectively; $\mathrm{K}_{\mathrm{f}}$ is the conditional formation constant of LPNA and the metal ion. Thus, measurements of the absorbances of LPNA at various metal ion concentrations allow the determination of $K_{f}$ by nonlinear leastsquares fit of Eq. (4).

For $\mathrm{Cu}(\mathrm{II})$, both $1: 1$ and 1:2 complexes are observed and the absorbance is given by:

$$
A=A_{0}[L] /[L]_{0}+A_{1} K_{1}[M][L] /[L]_{0}+A_{2} K_{1} K_{2}[M][L]^{2} /[L]_{0}
$$

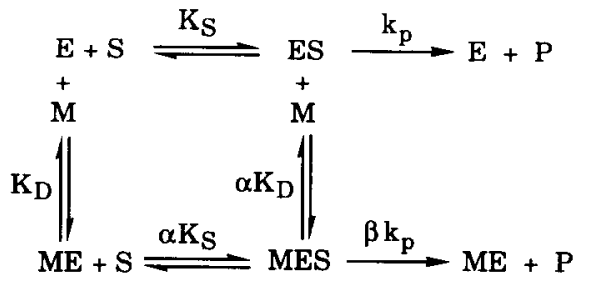

SCHEME 1. Kinetic mechanism for metaldependent aminopeptidase catalysis. Symbols: $\mathrm{E}=$ enzyme, $\mathrm{S}=$ substrate, $\mathrm{M}=$ metal, $P=$ products. $K_{D}$ is the dissociation constant of the enzyme-bound metal ion, $K_{S}$ the dissociation constant, and $\mathrm{k}_{\mathrm{p}}$ the turnover rate of the enzyme-substrate complex. $\alpha$ and $\beta$ are constants describing the changes in $\mathrm{K}_{\mathrm{S}}$ (or $\mathrm{K}_{\mathrm{D}}$ ) and $\mathrm{k}_{\mathrm{p}}$, respectively, upon metal-ion binding. 
where $A_{1}$ and $A_{2}$ are the absorbances for $1: 1$ and 1:2 Cu(II)-LPNA complexes, $\mathrm{K}_{1}$ and $\mathrm{K}_{2}$ their corresponding stepwise formation constants, and $[\mathrm{L}]_{0}$ and $[\mathrm{L}]$ the total and equilibrium concentrations of LPNA. The mass balance equations for $[\mathrm{M}]_{0}$ and $[\mathrm{L}]_{0}$ are:

$$
\begin{gathered}
{[M]_{0}=[M]\left(1+K_{1}[L]+K_{1} K_{2}[L]^{2}\right)} \\
{[L]_{0}=[L]+K_{1}[M][L]+2 K_{1} K_{2}[M][L]^{2} .}
\end{gathered}
$$

The values of $K_{1}$ and $K_{2}$ are determined from the nonlinear least-squares fit of the absorbances of LPNA at various metal ion concentrations based on Eqs. (5)-(7) using our own computer program. The presence of $\mathrm{Mn}$ (II) causes only a small change in the absorption of LPNA and the binding constant was determined by the conventional metal-competition method.

\section{Determination of the Thermodynamic Parameters}

Application of the transition state theory to a simple Michaelis-Menten mechanism, $\mathrm{E}+\mathrm{S} \leftrightarrow \mathrm{ES} \rightarrow$ products, reveals that the processes $\mathrm{E}+\mathrm{S} \rightarrow \mathrm{ES}$ and $\mathrm{ES} \rightarrow$ $E S^{\ddagger}$ are governed by the kinetic parameters $1 / \mathrm{K}_{\mathrm{M}}$ and $\mathrm{k}_{\text {cat }}$, respectively [10]. Where $\mathrm{E}$ and $\mathrm{S}$ denote the enzyme and the substrate, ES and $\mathrm{ES}^{\ddagger}$ are the ES complexes in the ground state and in the transition state, respectively. Therefore a plot of $\ln \mathrm{k}_{\mathrm{cat}}$ versus $1 / \mathrm{T}$ allows the determination of the activation energy, $\mathrm{Ea}$, for $\mathrm{ES} \rightarrow \mathrm{ES}^{\ddagger}$. Other thermodynamic parameters for this transformation at a given temperature can be estimated by the following relations: $\Delta \mathrm{G}^{\ddagger}=\mathrm{RT}$. $\ln \left(\mathrm{k}_{\mathrm{B}} \mathrm{T} / \mathrm{k}_{\text {cat }} \mathrm{h}\right), \Delta \mathrm{H}^{\ddagger}=\mathrm{Ea}-\mathrm{RT}, \Delta \mathrm{S}^{\ddagger}=\left(\Delta \mathrm{H}^{\ddagger}-\Delta \mathrm{G}^{\ddagger}\right) / \mathrm{T}$, where $\mathrm{k}_{\mathrm{B}}, \mathrm{h}$, and $\mathrm{R}$ are the Boltzmann, Planck, and gas constants; other thermodynamic functions have the usual meanings. On the other hand, the values of $\Delta \mathrm{H}$ and $\Delta \mathrm{S}$ for the process $E+S \rightarrow E S$ can be determined from the plot of $\ln \left(1 / \mathrm{K}_{\mathrm{M}}\right)$ versus $1 / \mathrm{T}$ and the value of $\Delta \mathrm{G}$ at a given temperature is calculated by: $\Delta \mathrm{G}=\Delta \mathrm{H}-\mathrm{T} \Delta \mathrm{S}$.

\section{RESULTS}

\section{Effects of Metal Ions on Enzyme Activity}

As the two aminopeptidases from pronase were very similar [4], only aminopeptidase-I was investigated. This enzyme exhibits a considerable activity against LPNA even in the absence of metal ions and its activity is unaffected by the presence of $1 \mathrm{mM}$ of 1,10-phenanthroline. These results indicate that AP-I does not necessarily require a metal ion for activity. In the presence of various metal ions, three different types of variation in enzyme activity against LPNA (expressed as $v /[E]_{0}$ ) were observed as demonstrated in Figure 1. For akaline earth metal ions, the enzyme activity increases and finally levels off as the metal ion concentration increases (e.g., Fig. $1 \mathrm{~A}$ for $\mathrm{Ca}(\mathrm{II})$ ). For $\mathrm{Mn}(\mathrm{II})$, $\mathrm{Co}(\mathrm{II})$, and $\mathrm{Zn}(\mathrm{II}$ ), the activity increases as metal ion concentration increases but decreases at large metal ion concentrations (e.g., Fig. 1B for $\mathrm{Mn}(\mathrm{II})$ ). For $\mathrm{Cu}(\mathrm{II})$ and $\mathrm{Ni(II),} \mathrm{the}$ 

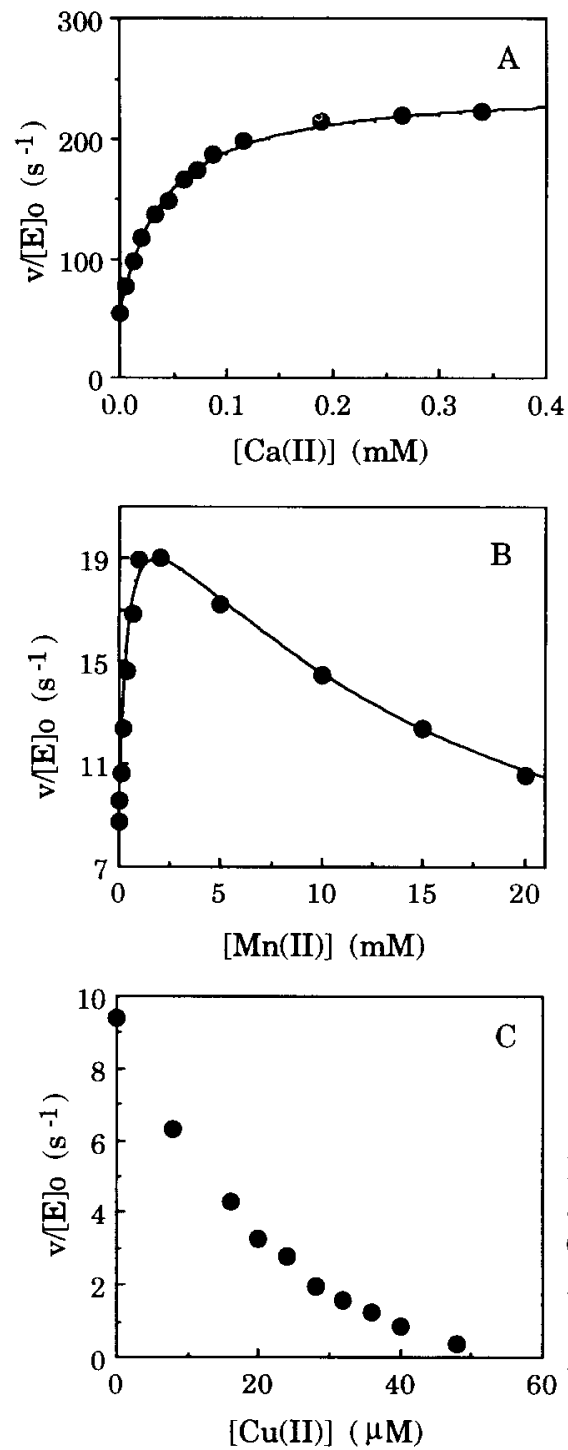

FIGURE 1. Dependence of the activity of AP-I against LPNA on metal ion concentrations for (A) $\mathrm{Ca}(\mathrm{II})$, (B) $\mathrm{Mn}$ (II), and (C) $\mathrm{Cu}(\mathrm{II}) .1 \mu \mathrm{M}$ of AP-I solution containing the appropriate metal ion was incubated at $\mathrm{pH} 8.0$ and $25^{\circ} \mathrm{C}$ for $30 \mathrm{~min}$. An aliquot of the enzyme solution was assayed against LPNA ( $1 \mathrm{mM}$ for A; $0.1 \mathrm{mM}$ for $\mathrm{B}$ and $C$ ) in the same buffer as used in the incubation.

activity decreases monotonically as the metal ion concentration increases (e.g., Fig. 1C for $\mathrm{Cu}(\mathrm{II})$ ). To reveal the effect of metal-substrate interaction on enzyme activity at low concentrations of metal ions $(0.1 \mathrm{M}$ or less, because of poor solubility), low substrate concentration $(0.1 \mathrm{M})$ was used in Fig. $1 \mathrm{~B}$ and $\mathrm{C}$. These three classes of activity-variations will be discussed in the following sections.

Determination of $\alpha, \beta$, and $\mathrm{K}_{\mathrm{D}}$

The values of $\mathrm{k}_{\text {cat }}, \mathrm{K}_{\mathrm{M}}$, and $\mathrm{k}_{\mathrm{cat}} / \mathrm{K}_{\mathrm{M}}$ for the hydrolysis of LPNA catalyzed by AP-I in $10 \mathrm{mM}$ Hepes (pH 8.0), $0.1 \mathrm{M} \mathrm{NaCl}$ at $25^{\circ} \mathrm{C}$ were determined at various concentrations of $\mathrm{Ca}(\mathrm{II})$ as demonstrated in Figure 2. Gradual increases in $\mathbf{k}_{\text {cat }}$ (curve A) and $\mathrm{k}_{\text {cat }} / \mathrm{K}_{M}$ (curve $\mathrm{C}$ ) and decrease in $\mathrm{K}_{M}$ (curve B) were observed as $\mathrm{Ca}(\mathrm{II})$ was increased. Nonlinear least-squares fits of the kinetic parameters to 
Eqs. (1), (2), or (3) were performed as illustrated by the solid curves that were drawn through the data points in Figure 2. The values of $\alpha, \beta, \beta / \alpha$, and $\mathrm{K}_{\mathrm{D}}$ obtained from different plots of Figure 2 were in excellent agreement with each other and their average values are $0.18,2.24,12.4$, and $0.14 \mathrm{mM}$, respectively. Similar procedures were also employed to $\mathrm{Mg}$ (II), $\mathrm{Sr}$ (II), and $\mathrm{Ba}(\mathrm{II})$ and the obtained values of $\alpha, \beta$, and $\mathrm{K}_{\mathrm{D}}$ were also given in Table 1 .

\section{Determination of the Binding Constants of LPNA and Metal Ions}

The absorption spectra of LPNA taken at various [Ni(II)] in $10 \mathrm{mM}$ Hepes (pH 8.0 ), $0.1 \mathrm{NaCl}$ at $25^{\circ} \mathrm{C}$ were shown in Figure 3. The spectra exhibited two isosbestic points at 268 and $344 \mathrm{~nm}$. Nonlinear least-squares fit of the absorbance changes $(\lambda=320 \mathrm{~nm})$ at various [Ni(II)] to Eq. (4) (represented by the solid curve in the inset of Fig. 3) gave a conditional formation constant of 950 $\mathbf{M}^{-1}$ for the Ni(II)-LPNA complex. Similar variations in the absorption spectra, with exactly the same isosbestic points, were observed for $\mathrm{Zn}$ (II) and $\mathrm{Co}$ (II). The values of $\mathrm{K}_{\mathrm{f}}$ for these two metals were also given in Table 1 .

Two stages of variations in the absorption spectra of LPNA were observed upon the addition of $\mathrm{Cu}(\mathrm{II})$. The spectra exhibited two sets of isosbestic points
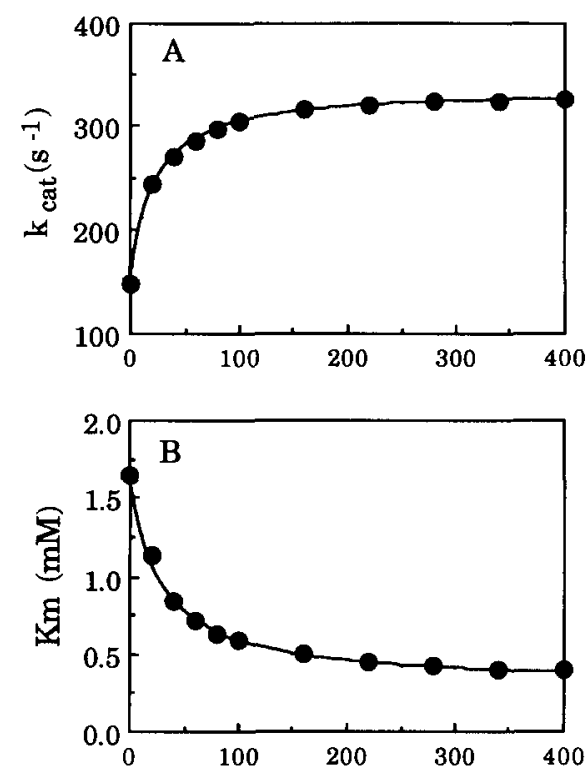

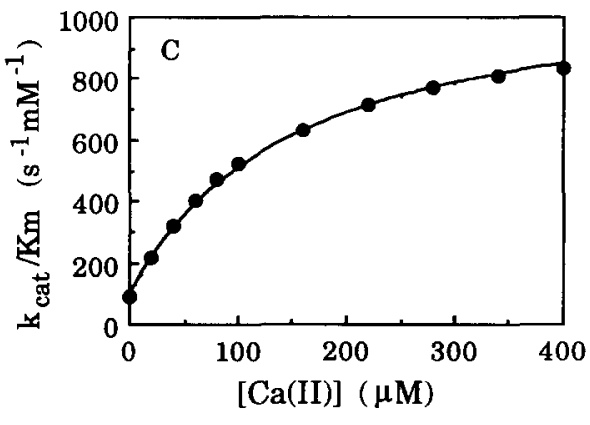

FIGURE 2. (A) Dependence of $k_{\text {cat }}$ on $\mathrm{Ca}(\mathrm{II})$. The solid curve was calculated by Eq. (1) using $\alpha=0.18, \beta=2.26, \mathrm{~K}_{\mathrm{D}}=0.11 \mathrm{mM}$. (B) Dependence of $\mathrm{K}_{M}$ on [Ca(II)]. The solid curve was calculated by Eq. (2) using $\alpha=0.18, \mathrm{~K}_{\mathrm{D}}=0.16 \mathrm{mM}$. (C) Dependence of $\mathrm{k}_{\text {cat }} / \mathrm{K}_{\mathrm{M}}$ on [Ca(II)]. The solid curve was calculated by Eq. (3) using $\alpha=0.18, \beta=$ $2.20, \mathrm{~K}_{\mathrm{D}}=0.15 \mathrm{mM}$. 
TABLE 1. Kinetic Parameters for Metal-Dependent AP-I and Formation Constants of Metal-LPNA Complexes ${ }^{\mathrm{a}, \mathrm{b}}$

\begin{tabular}{lccccc}
\hline Metal ion & $\alpha$ & $\beta$ & $\beta / \alpha$ & $\mathrm{K}_{\mathrm{D}}(\mathrm{mM})$ & $\mathrm{K}_{\mathrm{f}}\left(\mathrm{M}^{-1}\right)$ \\
\hline None & 1.00 & 1.00 & 1.00 & - & - \\
$\mathrm{Mg}(\mathrm{II})$ & 0.25 & 0.36 & 1.43 & 3.3 & - \\
$\mathrm{Ca}(\mathrm{II})$ & 0.18 & 2.24 & 12.4 & 0.14 & - \\
$\mathrm{S}$ (II) & 0.34 & 1.44 & 4.24 & 1.8 & - \\
$\mathrm{Ba}(\mathrm{II})$ & 0.49 & 1.55 & 3.16 & 2.1 & 70 \\
$\mathrm{Mn}(\mathrm{II})$ & 0.24 & 0.74 & 3.08 & 0.40 & 160 \\
$\mathrm{Co}(\mathrm{II})$ & 0.13 & 0.61 & 4.69 & $0.67 \mu \mathrm{M}$ & 950 \\
$\mathrm{Zn}(\mathrm{II})$ & 0.57 & 0.71 & 1.24 & 0.06 & - \\
$\mathrm{Ni}(\mathrm{II})$ & 0.94 & 0.43 & 0.46 & 0.34 & - \\
\hline
\end{tabular}

${ }^{a}$ Measured at $25^{\circ} \mathrm{C}$ in $10 \mathrm{mM}$ Hepes, $0.1 \mathrm{M} \mathrm{NaCl}, \mathrm{pH} 8.0$.

${ }^{b} \mathrm{~K}_{\mathrm{s}}=1.6 \mathrm{mM}, \mathrm{k}_{\mathrm{p}}=150 \mathrm{~s}^{-1}$.

${ }^{c}$ No interactions were observed for LPNA and the alkaline earth metals.

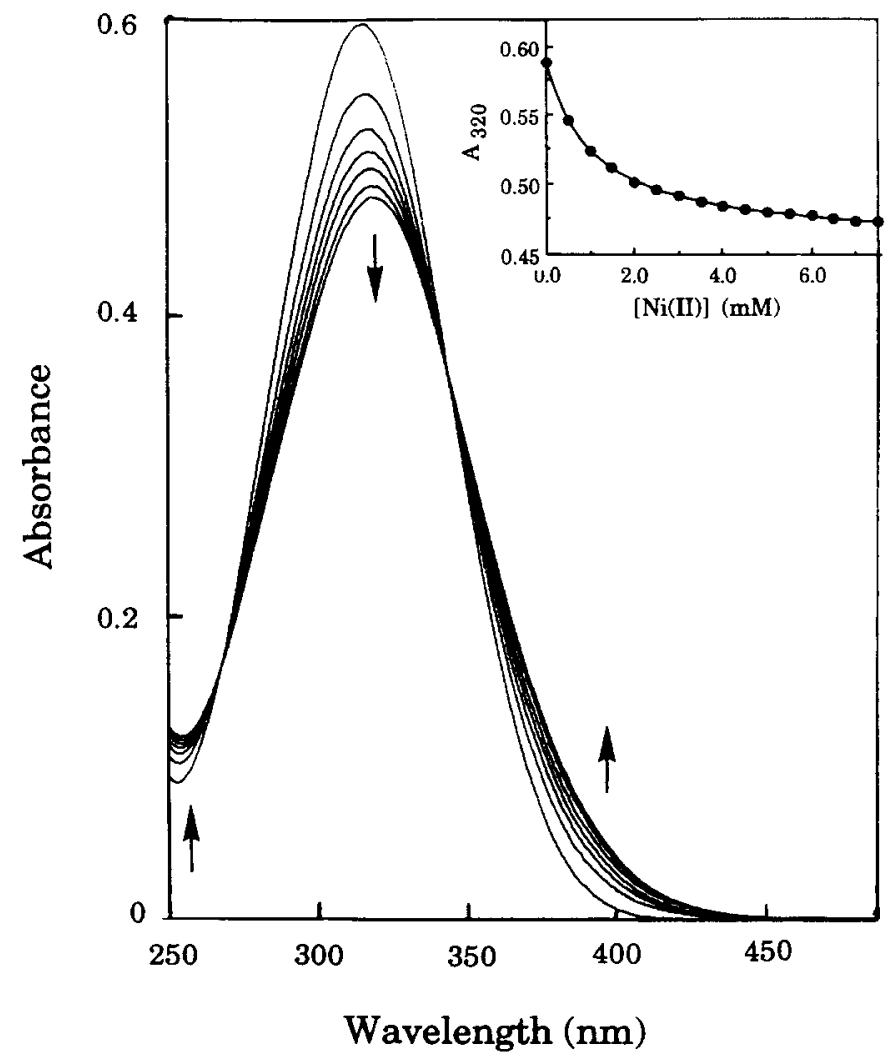

FIGURE 3. Absorption spectra of $50 \mu \mathrm{M}$ LPNA in $10 \mathrm{mM}$ Hepes (pH 8.0), $0.1 \mathrm{M} \mathrm{NaCl}$ at various [ $\mathrm{Ni}(\mathrm{II})$ ]. The arrows indicate the direction of absorption change as [Ni(II)] increases. Two isosbestic points at 268 and $344 \mathrm{~nm}$ were observed. Inset: absorbance changes at $320 \mathrm{~nm}$ at various [Ni(II)]. The solid curve was calculated by Eq. (4) using a formation constant of $950 \mathrm{M}^{-1}$. 
at $278,327 \mathrm{~nm}$ and $276,343 \mathrm{~nm}$, respectively. The two stages of absorption changes are due to the formation of $1: 2$ and 1:1 Cu(II)-LPNA complexes, respectively. Nonlinear least-squares fit of the biphasic absorbance changes $(\lambda=315 \mathrm{~nm})$ at various $[\mathrm{Cu}(\mathrm{II})]$ to Eqs. (5)-(7) gave two stepwise formation constants of $1.1 \times 10^{6}$ and $4.2 \times 10^{5} \mathrm{M}^{-1}$.

The formation of the metal-LPNA complexes causes a decrease in free LPNA concentration and hence a concomitant drop in enzyme activity because the metal-bound substrate is not hydrolyzed. With the known formation constants, the free substrate concentration can be calculated by $[S]=[S]_{0} /\left(1+K_{\mathrm{f}}[\mathrm{M}]\right)$. The use of the free substrate concentration allowed the determination of $\alpha, \beta$, and $\mathrm{K}_{\mathrm{D}}$ for the metal-incubated AP-I by the same procedures described in the previous section; the results were given in Table 1.

According to Scheme 1 , the activities (in terms of $v /[E]_{0}$ ) at various metal ion concentrations can be expressed as [9]:

$$
\frac{\mathrm{v}}{[\mathrm{E}]_{0}}=\frac{\mathrm{k}_{\mathrm{p}}[\mathrm{S}]\left(\alpha \mathrm{K}_{\mathrm{D}}+\beta[\mathrm{M}]\right) /\left(\alpha \mathrm{K}_{\mathrm{D}}+[\mathrm{M}]\right)}{\mathrm{K}_{\mathrm{s}}\left(\mathrm{K}_{\mathrm{D}}+[\mathrm{M}]\right) /\left(\mathrm{K}_{\mathrm{D}}+[\mathrm{M}] / \alpha\right)+[\mathrm{S}]}
$$

As an example, the values of $\mathrm{v} /[\mathrm{E}]_{0}$ at various [Mn(II)], calculated from Eq. (8) using $[S]=[S]_{0} /\left(1+K_{f}[M]\right)$ and the parameters listed in Table 1 , were represented by the solid curve in Figure $1 \mathrm{~B}$. For $\mathrm{Ca}(\mathrm{II})$, which exhibits no appreciable binding with LPNA, $[\mathrm{S}]=[\mathrm{S}]_{0}$ was used in the calculation of $\mathrm{v} /[\mathrm{E}]_{0}$ and the results were expressed as the solid curve in Figure 1A. Both curves agree with the experimental data very well.

\section{Determination of the Thermodynamic Parameters}

Because $\mathrm{Ca}$ (II) exhibits the most prominent effect on enzyme activity, the thermodynamic parameters for the enzyme-catalyzed reaction in the absence or presence of $\mathrm{Ca}$ (II) were determined to obtain further insights into the role of the metal ion in enzyme catalysis. Typical plots of $\ln k_{c a t}$ or $\ln \left(1 / K_{M}\right)$ versus $1 / \mathrm{T}$ for the hydrolysis of LPNA catalyzed by AP-I in the presence of $5 \mathrm{mM}$ $\mathrm{CaCl}_{2}$ were demonstrated in Figure 4. Linear least-squares fits of the data gave an activation energy of $7.5 \pm 0.4 \mathrm{kcal} / \mathrm{mol}$ for the process $\mathrm{ES} \rightarrow E S^{\ddagger}$ from the plot of $\ln \mathrm{k}_{\text {cat }}$ vs. $1 / \mathrm{T}$ and $\Delta \mathrm{H}=-4.7 \pm 0.4 \mathrm{kcal} / \mathrm{mol}, \Delta \mathrm{S}=0.6 \pm 0.1 \mathrm{cal} \cdot \mathrm{K}^{-1}$ for $\mathrm{E}+\mathrm{S} \rightarrow \mathrm{ES}$ from the plot of $\ln \left(1 / \mathrm{K}_{\mathrm{M}}\right)$ vs. $1 / \mathrm{T}$. Other thermodynamic parameters (at $25^{\circ} \mathrm{C}$ ) were calculated using the relations described in the experimental section; the results are given in Table 2 . Similar procedures were also employed to the enzyme-catalyzed reactions under the metal-free conditions and the obtained thermodynamic parameters are also given in Table 2. The activation free energies for the process $\mathrm{E}+\mathrm{S} \rightarrow \mathrm{ES} \mathrm{S}^{\ddagger}$, calculated from the data in Table 2, were 10.8 and $9.4 \mathrm{kcal} / \mathrm{mol}$ for the metal-free and the $\mathrm{Ca}(\mathrm{II})$-activated enzymes, respectively.

\section{DISCUSSION}

Most aminopeptidases contain an intrinsic catalytic-essential zinc ion [11-15]. Addition of different metal ions to a second metal-binding site or formation of hybrids of metal ions on both binding sites modify the enzyme activity to various extents [16-18]. The aminopeptidase reported in this study still exhibits signifi- 


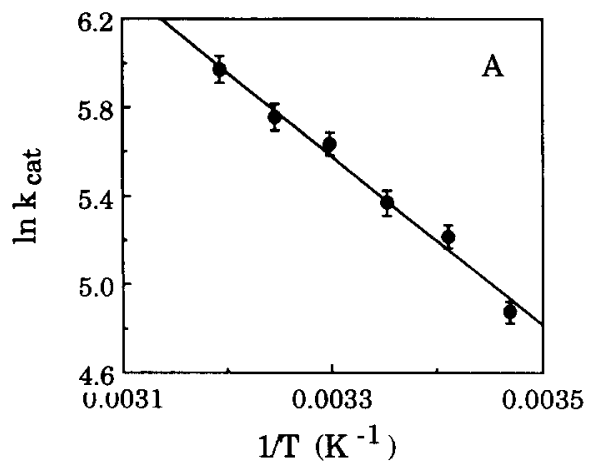

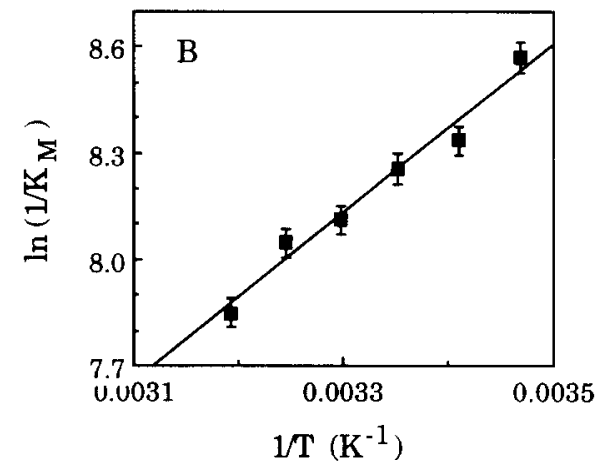

FIGURE 4. Plots of (A) $\ln \mathrm{k}_{\text {cat }}$ versus $1 / \mathrm{T}$ and (B) $\ln \left(1 / \mathrm{K}_{\mathrm{M}}\right)$ versus $1 / \mathrm{T}$ for the hydrolysis of LPNA catalyzed by $1 \mathrm{nM}$ of AP-I in the presence of $5 \mathrm{mM} \mathrm{CaCl}_{2}$ in $10 \mathrm{mM}$ Hepes, $\mathrm{pH}$ 8.0.

cant activity against LPNA in the absence of metal ions and its activity was unaffected by the presence of 1,10-phenanthroline, indicating that this enzyme does not necessarily require a metal ion for activity. The observed conditional stability constants $\left(1 / \mathrm{K}_{\mathrm{D}}\right)$ for the enzyme-bound metal ions are in the range of $10^{2}-10^{6} \mathrm{M}^{-1}$, which are much smaller than that of an ordinary metalloenzyme $\left(1 / K_{D}>10^{8} \mathrm{M}^{-1}\right)$, in which the metal ion is considered to be an integral part of the protein. Thus, it may not be appropriate to classify it as a metalloenzyme. The metal ions was found to be indispensable for enzyme activity when one of the histidines in the enzyme was modified by diethylpyrocarbonate. The activity of the modified enzyme in the presence or absence of $\mathrm{Ca}$ (II) differed by more than two orders of magnitude [4] indicating that $\mathrm{Ca}$ (II) is catalytically important in enzyme catalysis. This enzyme seems to possess some characteristics of both the metallo- and nonmetallo-aminopeptidase.

TABLE 2. Thermodynamic Parameters for the Hydrolysis of LPNA Catalyzed by AP-I at $25^{\circ} \mathrm{C}$ in the Absence or Presence of $\mathrm{Ca}(\mathrm{II})^{\mathrm{a}}$

\begin{tabular}{|c|c|c|c|c|c|c|c|}
\hline \multirow[b]{2}{*}{ [Ca(II)] } & \multicolumn{3}{|c|}{$\mathrm{E}+\mathrm{S} \rightarrow \mathrm{ES}$} & \multicolumn{4}{|c|}{$\mathrm{ES} \rightarrow \mathrm{ES}^{\ddagger}$} \\
\hline & $\Delta \mathrm{G}$ & $\Delta \mathrm{H}$ & $\Delta \mathrm{S}$ & $\Delta \mathrm{G}^{\ddagger}$ & $\Delta \mathrm{H}^{\ddagger}$ & $\Delta \mathrm{S}^{\ddagger}$ & $\mathrm{Ea}$ \\
\hline 0 & -3.9 & -2.6 & 4.5 & 14.7 & 5.1 & -32 & 5.7 \\
\hline $5 \mathrm{mM}$ & -4.9 & -4.7 & 0.6 & 14.3 & 7.0 & -24 & 7.5 \\
\hline
\end{tabular}

\footnotetext{
${ }^{\mathrm{a}}$ The units for $\Delta \mathrm{G}, \Delta \mathrm{H}$, and Ea are $\mathrm{kcal} / \mathrm{mol}$ and $\Delta \mathrm{S}$ is in cal $/ \mathrm{K}$. Ea was obtained from the plot of
} $\ln \mathrm{k}_{\text {cat }}$ vs. $1 / \mathrm{T} ; \Delta \mathrm{H}$ and $\Delta S$ were obtained from the plot of $\ln \left(1 / \mathrm{K}_{\mathrm{M}}\right)$ vs. $1 / \mathrm{T}$. 
The activity of AP-I against LPNA was found to be influenced by the presence of metal ions. A decrease in $\mathrm{K}_{\mathrm{M}}$ (i.e., $\alpha<1$ ) was observed for all the metal ions examined (Table 1) suggesting an enhanced substrate affinity probably due to a stabilization of the ES complex through the interaction of the enzyme-bound metal ion and the nucleophilic groups of the substrate. The $\mathbf{k}_{\text {cat }}$ 's were increased (i.e., $\beta>1$ ) by the presence of $\mathrm{Ca}(\mathrm{II}), \mathrm{Sr}$ (II), or $\mathrm{Ba}$ (II) and decreased by the rest of metal ions tested, whereas an enhanced activity (i.e., $\beta / \alpha>1$ ) was observed for most of the metal ions examined except $\mathrm{Ni}$ (II). $\mathrm{Ca}$ (II) was found to exhibit the most prominent effect on enzyme activity.

The spectral changes of LPNA induced by the binding of some transition metal ions were utilized to determine the stability constants for the LPNA-bound metal ions. LPNA binds $\mathrm{Cu}$ (II) very tightly, as revealed by the large stepwise formation constants. As a result, very little free LPNA will be left when $[\mathrm{Cu}(\mathrm{II})]>0.5[\mathrm{LPNA}]$. For example, in a typical assay of AP-I ([E] $\sim 1 \mathrm{nM})$ with $0.1 \mathrm{mM}$ LPNA, the fraction of the unbound LPNA is $8.0 \%$ in the presence of $0.05 \mathrm{mM} \mathrm{Cu}(\mathrm{II})$ and only $1.4 \%$ in the presence of $0.1 \mathrm{mM} \mathrm{Cu}(\mathrm{II})$. The decrease in free LPNA concentration will result in a concomitant decrease in enzyme activity, as seen in Figure 1C. Consequently, the effect of $\mathrm{Cu}$ (II) on the catalytic behavior of AP-I cannot be investigated by the kinetic method using the substrate LPNA. The decrease in enzyme activity at high concentrations of some transition metal ions (e.g., Fig. 1B) also resulted from the complexation of the substrate and the metal ions; corrections for the free substrate concentrations have to be made in order to obtain reliable kinetic parameters.

The thermodynamic parameters for $\mathrm{Ca}$ (II)-activated AP-I were also determined to get a further insight into the role of the metal ions in enzyme catalysis. The obtained free energy changes for the processes $E+S \rightarrow E S \rightarrow E S^{\ddagger}$ are illustrated diagrammatically in Figure 5. Binding of $E$ and $S$ to form $E S$ is energetically favorable $(\Delta G<0)$ indicating a stabilization of the ES complex probably due to the complementary structures of the substrate and the active site of the enzyme. In contrast, the transformation of $\mathrm{ES}$ to $\mathrm{ES}^{\ddagger}$ is unfavorable $(\Delta G>0)$ because of the activation energy of the bond making and breaking. Both the enthalpy and the entropy were found to be crucial in destabilizing $E S^{\ddagger}$. A positive enthalpy indicates that substantial conformational changes may occur during the conversion of ES to $\mathrm{ES}^{\ddagger}$. On the other hand, a large negative value of the entropy (Table 2) suggests that some of the molecular motions in the ES complex may become restricted or even frozen as ES is converted to $\mathrm{ES}^{\ddagger}$. In the

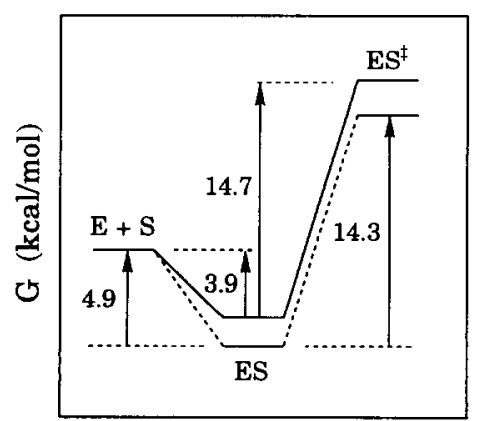

Reaction coordinate
FIGURE 5. Diagrammatic representation of the Gibbs free energy changes illustrating the conversions of $\mathrm{E}+\mathrm{S} \rightarrow \mathrm{ES} \rightarrow \mathrm{ES}^{\ddagger}$ for the hydrolysis of LPNA catalyzed by AP-I in the absence (solid line) or presence (dashed line) of $5 \mathrm{mM} \mathrm{CaCl}_{2}$. 
presence of $\mathrm{Ca}$ (II), ES is stabilized by $\sim 1 \mathrm{kcal} / \mathrm{mol}$ and $\mathrm{ES}^{\ddagger}$ by $\sim 1.4 \mathrm{kcal} / \mathrm{mol}$. The stabilization of ES by the presence of $\mathrm{Ca}(\mathrm{II})$ is reflected by a smaller $\mathrm{K}_{\mathrm{M}}$ value compared to that of the metal-free AP-I. The activation free energies for the process $\mathrm{E}+\mathrm{S} \rightarrow \mathrm{ES}^{\ddagger}$ were found to be 10.8 and $9.4 \mathrm{kcal} / \mathrm{mol}$ for the metal-free and the $\mathrm{Ca}(\mathrm{II})$-activated AP-I, respectively. The difference of $\sim 1.4$ $\mathrm{kcal} / \mathrm{mol}$ in the activation free energy may account for the enhanced enzyme activity ( $\beta / \alpha \sim 12)$ by the presence of $\mathrm{Ca}(\mathrm{II})$.

We thank the National Science Council of the Republic of China for financial support of this research.

\section{REFERENCES}

1. Bioactive Molecules, Vol. 8: Metalloproteins, S. Otska and T. Yamanaka, Eds. Elsevier, Amsterdam, 1988, pp. 343-391.

2. D. M. Christianson and W. N. Lipscomb, Acc. Chem. Res. 22, 62 (1989).

3. B. W. Matthews, Acc. Chem. Res. 21, 333 (1988).

4. S.-H. Yang, C.-H. Wu, and W.-Y. Lin, submitted to Biochem. J.

5. J. F. Riordan and B. L. Vallee, Methods Enzymol. 158, 1 (1988).

6. B. Holmquist, Methods Enzymol. 158, 6 (1988).

7. D. S. Auld, Methods Enzymol. 158, 13 (1988).

8. G. P. Royer and T. P. Andrews, J. Biol. Chem. 248, 1807 (1973).

9. I. H. Segel, Enzyme Kinetics, John Wiley \& Sons, New York, 1975, pp. 227-231.

10. A. Fersht, Enzyme Structure and Mechanism, 2nd edn., Freeman, New York, 1985, pp. 311-346.

11. F. H. Carpenter and J. M. Vahl, Biochemistry 248, 294 (1973).

12. S. R. Himmelhoch, Arch. Biochem. Biophys. 134, 597 (1969).

13. J. M. Prescott and S. H. Wilkes, Methods Enzymol. 45, 530 (1976).

14. J. Rodriguez-Absi and J. M. Prescott, Arch. Biochem. Biophys. 186, 383 (1978).

15. F. W. Wagner, L. E. Ray, M. A. Ajabnoor, P. E. Ziemba, and R. L. Hall, Arch. Biochem. Biophys. 197, 63 (1979).

16. H. E. Van Wart and S. H. Lin, Biochemistry 20, 5682 (1981).

17. M. P. Allen, A. H. Yamada, and F. H. Carpenter, Biochemistry 22, 3778 (1983).

18. J. M. Prescott, F. M. Wagner, B. Holmquist, and B. L. Vallee, Biochemistry 24, 5350 (1985).

Received January 3, 1994; accepted March 16, 1994 